\title{
Clinical outcome of platelet rich plasma versus steroid in treatment of frozen shoulder
}

\author{
Johney Juneja*, Mahendra Prakash Jain, Raghvendra Choubisa, A. K. Mehra, Ramesh Sen
}

Department of Orthopaedics, RNT, Udaipur, Rajasthan, India

Received: 09 June 2021

Revised: 16 September 2021

Accepted: 18 September 2021

\author{
*Correspondence: \\ Dr. Johney Juneja, \\ E-mail: johney.johney2008@gmail.com
}

Copyright: (c) the author(s), publisher and licensee Medip Academy. This is an open-access article distributed under the terms of the Creative Commons Attribution Non-Commercial License, which permits unrestricted non-commercial use, distribution, and reproduction in any medium, provided the original work is properly cited.

\begin{abstract}
Background: Evaluate functional outcome of use of platelet rich plasma versus steroid in frozen shoulder. Methods: The study was conducted in Department of Orthopaedics in RNT Medical College, Udaipur. Adult patients with periarthritis shoulder (frozen shoulder or adhesive capsulitis) admitted to Trauma centre in Maharana Bhupal Government hospital attached with R.N.T. Medical College, Udaipur were included in this study after obtaining their informed, valid written consent. This is a prospective study from October 2018 to February 2020.

Results: Our study demonstrated that PRP is not inferior to CS in any of the measured parameters. Both of the groups experienced similar benefits from the injection therapies with no statistical differences detected in ROM or VAS scores at 1 week, 1 month and 3 months. No adverse effects were detected in either of the two groups.

Conclusions: We can conclude that both PRP and MPS showed efficacy on treating frozen shoulder. The current study provides strong evidence in support of a statistically significant effect of platelet concentrates in the treatment of frozen shoulder in vivo where steroid contraindicated or refused by patient. However, inj. Methylprednisolone has sudden onset of action because of anti-inflammatory action with respect to inj. PRP, so has better result at 1 week follow up post injection. But in long term (at 3 months follow up) inj. PRP has better effect in compared to Inj. MPS.
\end{abstract}

Keywords: Platelet rich plasma, Frozen shoulder, Corticosteroid

\section{INTRODUCTION}

The focus in orthopaedic surgery is changing. Whilst in the previous decades the main focus was to reconstruct destroyed structures, but nowadays the idea of biological repair of defect tissues gains more and more importance. This idea of a biological way to keep our own structures has been expanded to the ligaments and cartilage as well.

Chronic complex musculoskeletal injuries that are slow to heal pose challenges to physicians and researchers alike. Frozen shoulder is a common disorder which is characterised by pain and loss of movement. Its cause is poorly understood and its management is disputed because of lack of supporting evidence. ${ }^{1}$
Duplay, in 1872, used the term "peri-arthritis scapulohumerale" to describe the condition.1 In 1934, Codman introduced the term frozen shoulder and set certain criteria for diagnosis and management. ${ }^{1}$ Neviaser used the term adhesive capsulitis to reflect his findings at surgery and at post-mortem. ${ }^{1}$ Zuckerman and Cuomo defined the condition as one of uncertain aetiology characterised by substantial restriction of both active and passive movement in the shoulder occurring in the absence of a known intrinsic disorder of the shoulder. The aetiology remains unknown, although some aspects of the pathophysiology have recently been documented. ${ }^{2}$ The symptoms are generally self-limiting over one to three years. 
This syndrome is not a disease, since the underlying pathological changes may no doubt affect either, the joint capsule or the peri-articular tissue. Peri-arthritis of the shoulder, therefore, is a collective term for a number of different lesions of the shoulder, the only common features being pain and limitation of movement in the shoulder joint.

The etiology is apparently not well understood. WatsonJones claims it is usually the result of some strain or injury to the joint capsule, the sub- acromial bursa, or the surrounding fibrous tissue. However, this is not in accordance with the views expressed by Haggart and Carr who say that the majority of patients with this disability give no history of injury. ${ }^{3}$ The condition appears to be more common in females than males and the greatest incidence occurs in the $5^{\text {th }}$ and $6^{\text {th }}$ decades. Generally speaking, the lack of under-standing of the basic etiology has been responsible for much ineffectual treatment.

Management of this disorder focuses on restoring joint movement and reducing shoulder pain, involving antiinflammatory medications, physical therapy, and/or surgical intervention. Frozen shoulder, or adhesive capsulitis, is typically treated with physiotherapy, including myofascial release, massage, range of motion exercises and ultrasound to release the scar tissue that has formed. If these do not relieve the problem, the scar tissue is broken up by injecting the shoulder full of a solution made up of sterile water mixed with an anesthetic, allowing the numb shoulder to be gently manipulated. ${ }^{4}$ Although all these treatment are needed to "unfreeze" the shoulder, they do not strengthen the weakened rotator cuff or supraspinatus tendon, and, thus, usually do not completely alleviate the chronic pain that people with this condition experience. ${ }^{4}$

Another standard practice of modern medicine is to inject methylprednisolone or Depo-Medrol or to prescribe antiinflammatory medications when people are suffering from chronic pain as with this condition. Injection Depo-Medrol is an anti-inflammatory glucocorticoid for intra-articular injection approved for medical use in 1955. Depo-Medrol is in essential list of drugs of WHO.

Recently advent of orthobiologics in treating periarthritis shoulder has developed. Orthobiologics is a relatively newer science that involves application of naturally found materials from biological sources (for example, cell-based therapies), and offers exciting new possibilities to promote and accelerate bone and soft tissue healing. Platelet-rich plasma (PRP) is an orthobiologic that has recently gained popularity as an adjuvant treatment for musculoskeletal injuries. ${ }^{5}$ It is a volume of fractionated plasma from the patient's own blood that contains platelet concentrate. The platelets contain alpha granules that are rich in several growth factors, such as platelet-derived growth factor, transforming growth factor- $\beta$, insulin-like growth factor, vascular endothelial growth factor and epidermal growth factor, which play key roles in tissue repair mechanisms. ${ }^{6,7}$
Hence it is plausible to assume that PRP injection therapy can have a beneficial effect in the management of frozen shoulder.

Since there are very few studies evaluating the beneficial effect of PRP injection therapy versus injection methylprednisolone in the treatment of periarthritis shoulder, we conducted a novel study in the Department of Orthopedics, MB Government Hospital attached to RNT Medical College, Udaipur to assess its results and biological effects.

\section{Aims and objectives}

To compare the management of periarthritis shoulder (frozen shoulder or adhesive capsulitis) by autologous platelet rich plasma concentrate injections and methylprednisolone injection. To assess the results of above procedure in terms of benefits and complications.

\section{Frozen shoulder classifications ${ }^{13,14}$}

Frozen shoulder: Lundberg classification. Stages of frozen shoulder: Reeves. Arthroscopic stages of adhesive capsulitis: Neviaser.

\section{Frozen shoulder: Lundberg classification}

\section{Primary frozen shoulder}

Shoulder elevation <135 deg. Limitation of movement only at gleno-humeral articulation. Radiology normal. Other causes i.e. trauma, OA, RA, Hemiplegia etc. excluded

\section{Secondary frozen shoulder}

Decreased range of movement following trauma or other known cause.

\section{Stages of frozen shoulder: Reeves}

Painful stage: 10-36 weeks. Stiffness: 4-12 months. Recovery: 5-24 months.

\section{Arthroscopic stages of frozen shoulder: Nevasier}

Stage 1: Erythematous/ fibrinous synovium, patient presents as impingement.

Stage 2: Red, angry, thick synovium, thick, contracted interval, tight joint space adhesions in the inferior fold.

Stage 3: Pink synovium contracted inferior fold, tight joint space.

Stage 4: no evidence of synovitis, tight inferior fold and joint. 


\section{Management $^{12}$}

\section{Conservative measures to relieve pain}

Relative rest. Moist heat. Sedation to assist sleep at night. Analgesics- NSAIDs, often requires opioid analgesics. Physical Therapy. Shoulder Range of Motion Exercises. Avoid aggressive mobilization as it may prolong the course. Initially, home Exercises are performed hourly

\section{Oral corticosteroid}

NSAIDS and Subacromial Corticosteroid Injection are preferred- Oral Corticosteroids risk significant adverse effects. Dosing- Prednisone $20 \mathrm{mg}$ orally daily for 3-4 weeks. Efficacy- Superior to physical therapy or Acetaminophen is improved function and decreased pain in the first 1-2 months.

\section{Subacromial corticosteroid injection}

Indicated at 6 weeks for course refractory to conservative measures and physical therapy. Restart Shoulder Range of Motion Exercises at 1 week after injection.

\section{Surgical intervention}

Indicated for intolerable symptoms at 6-12 weeks refractory to above measures.

\section{Procedures}

\section{Careful Shoulder manipulation under general anesthesia-}

Exercise caution in patients with Osteoporosis, Osteopenia or Glenohumeral Instability, Risk of Proximal Humerus Fracture, Glenohumeral Dislocation, Rotator Cuff Tear.

\section{Capsular release by Shoulder arthroscopy}

Cervical Sympathetic Nerve blocks (used historically for refractory pain control).

\section{PRP in the management of adhesive capsulitis}

\section{Definition of platelet-rich plasma}

Platelet-rich plasma (PRP) is defined as autologous blood plasma, which has been enriched with platelets using centrifugation. A synonyme is autologous conditioned plasma (ACP). The postulated effect of PRP is gained due to several different growth factors, which stimulate the healing of soft tissues (such as ligaments), and bones orcartilage. ${ }^{15}$

\section{Historical background}

Schulte et al first described possibly beneficial effects of PRP in the 1960s. ${ }^{16,17}$ They did not pool the plasma but used conventional plasma for healing of wound defects. Therefore, only autologous blood without real centrifugation was used and the work did not gain international recognition. In 1993, Yamamoto et al described the use of PRP for haemostasis and after cardiac surgery. ${ }^{18}$ A detailed description of PRP preparation was published in 1996 and in 1997, the first clinical studywas published in the field of oral surgery. ${ }^{19,20}$ Thereafter, the use of PRP was popular amongst dental surgeons within the following years.

In 2006, Murray et al published the impact of a collagenplatelet rich plasma scaffold to stimulate healing of a central defect in the canine ACL. ${ }^{21}$ This research group expanded the knowledge gained from PRP on various aspects of ACL reconstruction. Whilst scientists have agreed, that PRP has the potential to gain significant influence on tissue repair in musculoskeletal surgery, its benefical impact remains to be proven in large randomized controlled trials. In addition, various co-factors such as, the method of preparation and the time of administration might have significantly high influence on our patients.

Autologous PRP injections were reportedly first used in 1987 in an open heart surgery. ${ }^{22}$ Over 20 years ago, PRP was used in the dental field for promoting accelerated wound healing in cancer patients following jaw reconstruction. Physicians have used PRP to aid bone healing after spinal injury and soft tissue recovery following plastic surgery. PRP therapy gained broad popularity in early 2009, when it was reported that two of the Pittsburgh Steelers received PRP for their ankle injuries before their triumph at the Super Bowl. Due to the media attention, PRP became an accepted though unproven treatment for sports-related injurie.23 Currently, PRP injections are being used in various applications, including orthopaedics, cardiovascular surgery, cosmetics, facio-maxillary surgery and urology. As a result, multiple studies are now underway to understand PRP's mechanism of action, refine the treatment, and formally demonstrate efficacy in placebo-controlled trials. ${ }^{24}$

\section{Platelet physiology and function}

A typical blood specimen comprises $93 \%$ red blood cells, $6 \%$ platelets, and $1 \%$ white blood cells. ${ }^{25}$ Platelets were first seen in the blood by French physician Alfred Donné in $1842 .{ }^{26}$ These are small discoid cells with a life span of about 7 to 10 days. Following injury that causes bleeding, platelets are activated and aggregate together to release their granules containing growth factors that stimulate the inflammatory cascade and healing process. Platelets are responsible for hemostasis, construction of new connective tissue and revascularization and most of the research over the past century has been focused on this primary function. ${ }^{24}$ Only in the Past two decades have we learned that platelet activation in the body releases healing proteins called growth factors. ${ }^{27}$ There are numerous growth factors with diverse functions, but cumulatively they may accelerate tissue and wound healing. The 
ideology behind PRP treatment is the reversal of the red blood cell: platelet ratio by decreasing red blood cells to $5 \%$ (which are less useful in the healing process) and more importantly concentrating platelets containing a powerful concoction of growth factors to $94 \% . .^{5}$ A normal platelet count in a healthy individual is between 150,000 and 450,000 cells per microliter of blood. Platelet concentrations of less than $1,000 \times 10 / \mathrm{ml}$ were not reliable for enhancing wound healing, and most studies have suggested that tissue reparative efficacy with PRP can be expected with a minimum increase of five times the normal concentration of platelets (approximately 1 million platelets $/ \mu \mathrm{l})$, whereas much higher concentrations did not show further enhancement of wound healing. The ideal concentration remains to be defined. The broad variability in platelet concentrating equipment and techniques used in different studies may alter platelet degranulation characteristics that could affect clinical outcomes, making interpretation of the results challenging. ${ }^{5}$

\section{Growth factors in platelet-rich plasma}

The notable components of PRP include transforming growth factor (TGF)- $\beta$, platelet derived growth factors (PDGF-AB and PDGF-BB), insulin-like growth factor (IGF), Vascular endothelial growth factors (VEGFs), Epidermal growth factor (EGFs) And fibroblast growth factor (FGF)-2. TGF- 11 and PDGF stimulate proliferation of mesenchymal cells. TGF- $\beta 1$ also stimulates extracellular matrix production, including collagen. ${ }^{5}$ Principally, these factors stabilize the damaged tissue during initial stages of tissue repair and direct the local mesenchymal and epithelial cells to migrate, divide and increase collagen and matrix synthesis, ultimately leading to fibrous connective tissue and scar formation. VEGF and FGF-2 are important for stimulating new blood vessel formation to bring nutrients and progenitor cells to the injury site; however, additional factors are also required for neo-vascularization. PRP is postulated to improve the early healing of tendon defects by over-expression of IGF1. The 70 amino acid polypeptide hormone IGF is a normal component of the plasma and is transported by IGFbinding proteins. IGF-1 storage in platelets is unclear, with few proteomic studies reporting it to be absent and most literature detecting IGF-1 in platelets; however, most studies have detected IGF-1 in PRP. ${ }^{25}$ For PRP's Role in multiple healing pathways, it deserves due consideration as an adjunctive therapy for specific applications. Under physiological conditions, these growth factors aid in wound healing and tissue regeneration after trauma. The underlying principle of PRP usage is to pool those factors to achieve a higher than normal effect. In addition, it is a more cost-effective method, than producing the different factors.

The simplicity of PRP application is defined by three steps (Figure 1). For most orthopedic use, which currently happens to be in an outpatient setting, the physician harvests the venous blood and transfers it to the centrifuge. Once the blood is in the centrifuge, processing usually takes between 5 and 20 minutes, and a sterile barrier may be necessary, depending on automation and centrifuge processing protocols. The current recommendations state that the platelet concentration should be raised between four and six times above the baseline concentration. After the centrifuge processes, the physician extracts PRP According to device instructions. The platelets collected in PRP are often activated by the addition of thrombin and calcium chloride, which induce the release of these factors from the alpha granules. With wider acceptance of PRP treatment, its application is selectively being adapted for use in the operating room while surgery is in progress. Research is ongoing to determine the best concentration, preparation and timing of the injections. We know of several techniques for PRP preparation (Figure 2), with multiple commercially available products (Table 2); however, their application has been confusing because each technique leads to a different product with potentially dissimilar biology and unknown relative efficacy.

There exist various devices for PRP preparation with different outcomes but the basic principles remain the same and are hereby explained:

At least $60 \mathrm{cc}$ of whole blood are drawn per patient. In order to prevent coagulation of the whole blood sodium citrate is added before the process of centrifugation. Using centrifugation, it is possible to separate the PRP from platelet-poor plasma and erythrocytes.

For clinical application in patients, a 5-fold concentration of the typical baseline blood platelet count is applied (1 000000 per $\mu \mathrm{l})$. Once injected, PRP might be further activated using various types of thrombin or collagen. Different companies have produced devices, which make harvesting of the PRP easier after the process of centrifugation by having installed a small syringe into the centrifuged syringe.

\section{DEPO-MEDROL (methylprednisolone acetate injectable suspension, USP)}

DEPO-MEDROL is an anti-inflammatory glucocorticoid for intramuscular, intra-articular, soft tissue, or intralesional injection. It is available in three strengths: 20 $\mathrm{mg} / \mathrm{mL}, 40 \mathrm{mg} / \mathrm{mL}, 80 \mathrm{mg} / \mathrm{mL}$.

Each $\mathrm{mL}$ of these preparations contains: Methylprednisolone acetate $20 \mathrm{mg}, 40 \mathrm{mg}, 80 \mathrm{mg}$. Polyethylene Glycol $335029.5 \mathrm{mg}, 29.1 \mathrm{mg}, 28.2 \mathrm{mg}$. Polysorbate $801.97 \mathrm{mg}, 1.94 \mathrm{mg}, 1.8 \mathrm{mg}$. Monobasic Sodium Phosphate $6.9 \mathrm{mg}, 6.8 \mathrm{mg}, 6.59 \mathrm{mg}$. Dibasic Sodium Phosphate USP $1.44 \mathrm{mg}, 1.42 \mathrm{mg}, 1.37 \mathrm{mg}$. Benzyl Alcohol added as a preservative $9.3 \mathrm{mg}, 9.16 \mathrm{mg}$, $8.88 \mathrm{mg}$.

DEPO-MEDROL sterile aqueous suspension contains methylprednisolone acetate which is the 6-methyl derivative of prednisolone. Methylprednisolone acetate is a white or practically white, odorless, crystalline powder 
which melts at about $215^{\circ}$ with some decomposition. It is soluble in dioxane, sparingly soluble in acetone, alcohol, chloroform, and methanol, and slightly soluble in ether. It is practically insoluble in water. $\mathrm{NaCl}$ added for $\mathrm{pH}$ adjust with $\mathrm{NaOH}$ and $\mathrm{HCl}(\mathrm{pH} 3-7)$.

Table 1: Summary of growth factors contained in platelet-rich plasma.

\begin{tabular}{|c|c|}
\hline Growth factor & Function \\
\hline $\begin{array}{l}\text { Transforming growth } \\
\text { factor-B (TGF- B) }\end{array}$ & $\begin{array}{l}\text { Stimulates undifferentiated mesenchymal cell proliferation } \\
\text { Regulates endothelial, fibroblastic, and osteoblastic mitogenesis } \\
\text { Regulates collagen synthesis and collagenase secretion } \\
\text { Regulates mitogenic effects of other growth factors } \\
\text { Stimulates endothelial chemotaxis and angiogenesis } \\
\text { Inhibits macrophage and lymphocyte proliferation }\end{array}$ \\
\hline $\begin{array}{l}\text { Fibroblast growth factor } \\
\text { (FGF) }\end{array}$ & $\begin{array}{l}\text { Promotes growth and differentiation of chondrocytes and osteoblasts } \\
\text { Mitogenetic for mesenchymal cells, chondrocytes, and osteoblasts }\end{array}$ \\
\hline $\begin{array}{l}\text { Platelet-derived growth } \\
\text { factor a and b (PDGF) }\end{array}$ & $\begin{array}{l}\text { Mitogenetic for mesenchymal cells and osteoblasts } \\
\text { Stimulates chemotaxis and mitogenesis in fi broblast, glial, or smooth muscle cells } \\
\text { Regulates collagenase secretion and collagen synthesis } \\
\text { Stimulates macrophage and neutrophil chemotaxis }\end{array}$ \\
\hline $\begin{array}{l}\text { Epidermal growth factor } \\
\text { (EGF) }\end{array}$ & $\begin{array}{l}\text { Stimulates endothelial chemotaxis or angiogenesis } \\
\text { Regulates collagenase secretion } \\
\text { Stimulates epithelial or mesenchymal mitogenesis }\end{array}$ \\
\hline $\begin{array}{l}\text { Vascular endothelial } \\
\text { growth factor (VEGF) }\end{array}$ & $\begin{array}{l}\text { Increases angiogenesis and vessel permeability } \\
\text { Stimulates mitogenesis for endothelial cells }\end{array}$ \\
\hline $\begin{array}{l}\text { Connective tissue growth } \\
\text { factor (CTGF) }\end{array}$ & $\begin{array}{l}\text { Promotes angiogenesis } \\
\text { Cartilage regeneration } \\
\text { Fibrosis and platelet adhesion }\end{array}$ \\
\hline $\begin{array}{l}\text { Insulin like growth factor } \\
\text { (ILGF } 1 \text { and 2) }\end{array}$ & $\begin{array}{l}\text { Chemotactic for fi broblasts and stimulates protein synthesis } \\
\text { Enhances bone formation }\end{array}$ \\
\hline Platelet factor 4 (PF-4) & $\begin{array}{l}\text { Stimulate the initial influx of neutrophils into wounds } \\
\text { Chemo-attractant for fibroblasts }\end{array}$ \\
\hline Interleukin 8 (IL-8) & $\begin{array}{l}\text { Pro-inflammatory mediator } \\
\text { Recruitment of inflammatory cells } \\
\text { Keratinocyte growth factor (KGF) Promote endothelial cell growth, migration, adhesion } \\
\text { and survival } \\
\text { Angiogenesis }\end{array}$ \\
\hline
\end{tabular}

\section{Clinical pharmacology}

Glucocorticoids, naturally occurring and synthetic, are adrenocortical steroids. Naturally occurring glucocorticoids (hydrocortisone and cortisone), which also have salt retaining properties, are used in replacement therapy in adrenocortical deficiency states. Their synthetic analogs are used primarily for their anti-inflammatory effects in disorders of many organ systems.

Glucocorticoids cause profound and varied metabolic effects. In addition, they modify the body's immune response to diverse stimuli.

\section{Mechanism of action}

Unbound glucocorticoids cross cell membranes and bind with high affinity to specific cytoplastic receptors, modifying transcription and protein synthesis. By this mechanism, glucocorticoids can inhibit leukocyte infiltration at the site of inflammation, interfere with mediators of inflammatory response, and suppress humoral immune responses. The anti-inflammatory actions of corticosteroids are though to involve phospholipase A2 inhibitory protein, lipocortins which control the biosynthesis of potent mediators of inflammation such as prostaglandins and leukotrienes.

\section{Available forms}

Methylprednisolone acetate (Depo-Medrol) is a fatsoluble ester of methylprednisolone and is formulated as an aqueous suspension to be administered by intramuscular, intra-articular, soft tissue, or intralesional injection only. It has the potential to cause subcutaneous atrophy in the area administered.

Methylprednisolone acetate is not indicated for intravenous use. The only formulation that should be given intravenously is methylprednisolone succinate (Solumedrol), a water-soluble ester of methylprednisolone. 


\section{METHODS}

The study was conducted in Department of Orthopaedics in RNT Medical College, Udaipur.

\section{Source of data}

Adult patients with periarthritis shoulder (frozen shoulder or adhesive capsulitis) admitted to Trauma centre in Maharana Bhupal Government hospital attached with R.N.T. Medical College, Udaipur were included in this study after obtaining their informed, valid written consent. This is a prospective study from October 2018 to February 2020 .

\section{Method of collection of data}

Sample size

The study included patients with periarthritis shoulder (frozen shoulder or adhesive capsulitis) admitted and examined according to protocol. Clinical and radiological investigations were carried out for preoperative evaluation. Venous blood collection of around $20 \mathrm{ml}$ was done for every patient and then centrifugation resulted in PRP concentrate of around 5-6 $\mathrm{ml}$ which was then injected at the site concerned.

Group A: The patients treated by PRP.

Group B: will be assigned for patient being treated by inj. MPS.

Patients were followed up at 1 week post injection, then after 1 month and then at 3 months.

A minimum of 25 cases each studied.

\section{Inclusion criteria}

Adults ( $>18$ years) males and females. Stage 2 and above cases of periarthritis shoulder (symptoms $>9$ months. ROM to $50 \%$ of other arm).

\section{Exclusion criteria}

Age below 18 years. Patient who is taking NSAIDs around the period of injection. Stage 1 peri-arthritis shoulder. Any associated fractures. Superficial infection. Any morbid conditions like severe diabetes. Patient not willing for injection. Bilateral symptoms.

\section{RESULTS}

In this study, there were $60 \%$ female patients and $40 \%$ were males. Maximum number of cases were idiopathic (54\%): Patients treated with PRP (44\%) and patients treated with MPS (64\%).
Table 2: Distribution of patients according to age and gender.

\begin{tabular}{|lll|}
\hline & PRP $(\mathbf{N}=25)$ & MPS $(\mathbf{N}=25)$ \\
\hline $\begin{array}{l}\text { Mean age } \\
\text { (years) }\end{array}$ & $56.16 \pm 9.16$ & $57.92 \pm 9.78$ \\
\hline Gender & & \\
\hline Male & $10(40 \%)$ & $10(40 \%)$ \\
\hline Female & $15(60 \%)$ & $15(60 \%)$ \\
\hline
\end{tabular}

Table 3: Comparisons of pain according to VAS during pre and post treatment.

\begin{tabular}{|lll|} 
Time interval & $\begin{array}{l}\text { PRP } \\
(\text { Mean } \pm \text { SD })\end{array}$ & $\begin{array}{l}\text { MPS } \\
(\text { Mean } \pm \text { SD })\end{array}$ \\
\hline Pre & $8.76 \pm 0.99$ & $8.48 \pm 0.80$ \\
\hline Post - 1 week & $5.60 \pm 2.75$ & $5.92 \pm 2.26$ \\
\hline Post - 1 month & $4.00 \pm 3.49$ & $3.92 \pm 2.67$ \\
\hline Post - 3 months & $3.12 \pm 3.85$ & $3.12 \pm 3.31$ \\
\hline P value & $<0.00001(\mathrm{~S})$ & $<0.00001(\mathrm{~S})$ \\
\hline Chi-square & 48.216 & 40.968 \\
\hline
\end{tabular}

Test of significance: Repeated measures ANOVA

Table 4: Pairwise comparisons among variables (PAIN).

\begin{tabular}{|c|c|c|c|c|c|}
\hline \multirow{2}{*}{ Pain } & \multirow{2}{*}{ Pain } & \multicolumn{2}{|l|}{ PRP } & \multicolumn{2}{|l|}{ MPS } \\
\hline & & $\mathbf{F}$ & $\begin{array}{l}\text { Sig. } \\
\text { value }\end{array}$ & $\mathbf{F}$ & $\begin{array}{l}\text { Sig. } \\
\text { value }\end{array}$ \\
\hline \multirow{3}{*}{ Pre } & $\begin{array}{l}\text { Post - } \\
1 \text { week }\end{array}$ & 1.537 & 0.230 & 3.291 & 0.041 \\
\hline & $\begin{array}{l}\text { Post - } 1 \\
\text { month }\end{array}$ & 1.301 & 0.303 & 0.319 & 0.811 \\
\hline & $\begin{array}{l}\text { Post - } 3 \\
\text { months }\end{array}$ & 2.157 & 0.111 & 0.153 & 0.926 \\
\hline \multirow{3}{*}{$\begin{array}{l}\text { Post - } \\
1 \text { week }\end{array}$} & Pre & 1.468 & 0.244 & 2.979 & 0.031 \\
\hline & $\begin{array}{l}\text { Post - } 1 \\
\text { month }\end{array}$ & 93.497 & 0.000 & 2.544 & 0.055 \\
\hline & $\begin{array}{l}\text { Post - } 3 \\
\text { months }\end{array}$ & 128.049 & 0.000 & 1.364 & 0.282 \\
\hline \multirow{3}{*}{$\begin{array}{l}\text { Post - } \\
1 \\
\text { month }\end{array}$} & Pre & 1.223 & 0.343 & 63.969 & 0.000 \\
\hline & $\begin{array}{l}\text { Post - } \\
1 \text { week }\end{array}$ & 189.088 & 0.000 & 3.031 & 0.029 \\
\hline & $\begin{array}{l}\text { Post - } 3 \\
\text { months }\end{array}$ & 45.141 & 0.000 & 4.951 & 0.003 \\
\hline \multirow{3}{*}{$\begin{array}{l}\text { Post - } 3 \\
\text { months }\end{array}$} & Pre & 14.973 & 0.000 & 2.097 & 0.101 \\
\hline & $\begin{array}{l}\text { Post - } \\
1 \text { week }\end{array}$ & 2.596 & 0.054 & 3.844 & 0.011 \\
\hline & $\begin{array}{l}\text { Post - } 1 \\
\text { month }\end{array}$ & 48.392 & 0.000 & 34.819 & 0.000 \\
\hline
\end{tabular}

Test applied: Adjustment for multiple comparisons: post hoc Bonferroni test. 
Table 5: Comparisons of forward flexion (in degrees) during pre and post treatment.

\begin{tabular}{|lll|}
\hline Time interval & $\begin{array}{l}\text { PRP } \\
(\text { Mean } \pm \text { SD) }\end{array}$ & $\begin{array}{l}\text { MPS } \\
(\text { Mean } \pm \text { SD) }\end{array}$ \\
\hline Pre & $52.80 \pm 22.93$ & $51.80 \pm 16.05$ \\
\hline Post - 1 week & $75.00 \pm 25.81$ & $69.60 \pm 23.28$ \\
\hline Post - 1 month & $90.20 \pm 34.36$ & $83.60 \pm 27.59$ \\
\hline Post - 3 months & $105.00 \pm 45.24$ & $92.80 \pm 36.93$ \\
\hline P value & $<0.00001(\mathrm{~S})$ & $<0.00001(\mathrm{~S})$ \\
\hline Chi-square & 55.956 & 35.544 \\
\hline
\end{tabular}

Test of significance: Repeated measures ANOVA

Table 6: Pairwise comparisons among variables (forward flexion).

\begin{tabular}{|c|c|c|c|c|c|}
\hline & & PRP & & MPS & \\
\hline Flexion & Flexion & $\mathbf{F}$ & $\begin{array}{l}\text { Sig. } \\
\text { value }\end{array}$ & $\mathbf{F}$ & $\begin{array}{l}\text { Sig. } \\
\text { value }\end{array}$ \\
\hline \multirow{3}{*}{ Pre } & $\begin{array}{l}\text { Post - } 1 \\
\text { week }\end{array}$ & 5.040 & 0.003 & 3.511 & 0.016 \\
\hline & $\begin{array}{l}\text { Post - } 1 \\
\text { month }\end{array}$ & 2.360 & 0.070 & 1.695 & 0.176 \\
\hline & $\begin{array}{l}\text { Post - } 3 \\
\text { month }\end{array}$ & 1.982 & 0.118 & 1.009 & 0.474 \\
\hline \multirow{3}{*}{$\begin{array}{l}\text { Post - } 1 \\
\text { week }\end{array}$} & Pre & 4.490 & 0.006 & 2.647 & 0.047 \\
\hline & $\begin{array}{l}\text { Post - } 1 \\
\text { month }\end{array}$ & 3.797 & 0.012 & 24.795 & 0.000 \\
\hline & $\begin{array}{l}\text { Post - } 3 \\
\text { months }\end{array}$ & 2.317 & 0.073 & 15.586 & 0.000 \\
\hline \multirow{3}{*}{$\begin{array}{l}\text { Post - } 1 \\
\text { month }\end{array}$} & Pre & 0.796 & 0.643 & 2.038 & 0.116 \\
\hline & $\begin{array}{l}\text { Post - } 1 \\
\text { week }\end{array}$ & 5.015 & 0.004 & 27.44 & 0.000 \\
\hline & $\begin{array}{l}\text { Post - } 3 \\
\text { months }\end{array}$ & 29.429 & 0.000 & 39.315 & 0.000 \\
\hline \multirow{3}{*}{$\begin{array}{l}\text { Post - } 3 \\
\text { months }\end{array}$} & Pre & 1.002 & 0.492 & 1.796 & 0.169 \\
\hline & $\begin{array}{l}\text { Post - } 1 \\
\text { week }\end{array}$ & 4.063 & 0.010 & 11.195 & 0.000 \\
\hline & $\begin{array}{l}\text { Post - } 1 \\
\text { month }\end{array}$ & 42.233 & 0.000 & 48.787 & 0.000 \\
\hline
\end{tabular}

Test applied: ANOVA.

Most of the patients (60\%) were injected with PRP in time frame of 3-6 months and with inj. MPS also in 3-6 months $(56 \%)$.

This table clearly depicts the statistically significant reduction in VAS scores after therapy with PRP as well as MPS over a period of time.

This table shows statistically significant increase in the degree of forward flexion after the therapy over a period of 3 months.

Table 4 shows statistically significant elevation in the degree of lateral elevation after PRP and MPS injections.
Table 7: Comparisons of lateral elevation during pre and post treatment $(n=25)$.

\begin{tabular}{|lll|}
\hline Time interval & $\begin{array}{l}\text { PRP } \\
(\text { Mean } \pm \text { SD })\end{array}$ & $\begin{array}{l}\text { MPS } \\
(\text { Mean } \pm \text { SD })\end{array}$ \\
\hline Pre & $52.60 \pm 16.56$ & $50.20 \pm 17.35$ \\
\hline Post - 1 week & $75.80 \pm 21.94$ & $67.80 \pm 22.89$ \\
\hline Post - 1 month & $89.40 \pm 28.15$ & $79.20 \pm 30.58$ \\
\hline Post - 3 months & $102.20 \pm 39.75$ & $89.20 \pm 40.09$ \\
\hline P value & $<0.00001(\mathrm{~S})$ & $<0.00001(\mathrm{~S})$ \\
\hline Chi-square & 46.572 & 45.444 \\
\hline
\end{tabular}

Test of significance: Repeated measures ANOVA

Table 8: Pairwise comparisons among variables (lateral flexion).

\begin{tabular}{|c|c|c|c|c|c|}
\hline & & PRP & & MPS & \\
\hline Lateral & Lateral & $\mathbf{F}$ & $\begin{array}{l}\text { Sig. } \\
\text { value }\end{array}$ & $\mathbf{F}$ & $\begin{array}{l}\text { Sig. } \\
\text { value }\end{array}$ \\
\hline \multirow{3}{*}{ Pre } & $\begin{array}{l}\text { Post - } \\
1 \text { week }\end{array}$ & 3.132 & 0.025 & 3.758 & .012 \\
\hline & $\begin{array}{l}\text { Post - } 1 \\
\text { month }\end{array}$ & 1.922 & .127 & 2.371 & .069 \\
\hline & $\begin{array}{l}\text { Post - } 3 \\
\text { months }\end{array}$ & 1.750 & 0.162 & 1.872 & .138 \\
\hline \multirow{3}{*}{$\begin{array}{l}\text { Post - } \\
1 \text { week }\end{array}$} & Pre & 3.951 & 0.10 & 3.092 & .026 \\
\hline & $\begin{array}{l}\text { Post - } 1 \\
\text { month }\end{array}$ & 37.087 & .000 & 40.850 & .000 \\
\hline & $\begin{array}{l}\text { Post - } 3 \\
\text { months }\end{array}$ & 13.927 & .000 & 18.680 & .000 \\
\hline \multirow{3}{*}{$\begin{array}{l}\text { Post - } 1 \\
\text { month }\end{array}$} & Pre & 2.717 & .044 & 1.887 & .133 \\
\hline & $\begin{array}{l}\text { Post - } \\
1 \text { week }\end{array}$ & 37.473 & .000 & 26.666 & .000 \\
\hline & $\begin{array}{l}\text { Post - } 3 \\
\text { months }\end{array}$ & 37.197 & .000 & 82.050 & .000 \\
\hline \multirow{3}{*}{$\begin{array}{l}\text { Post - } 3 \\
\text { months }\end{array}$} & Pre & 2.284 & .076 & 2.056 & .109 \\
\hline & $\begin{array}{l}\text { Post - } \\
1 \text { week }\end{array}$ & 15.476 & .000 & 16.966 & .000 \\
\hline & $\begin{array}{l}\text { Post } 1 \\
\text { month }\end{array}$ & 65.735 & .000 & 128.360 & .000 \\
\hline
\end{tabular}

Test applied: Adjustment for multiple comparisons: post hoc Bonferroni test.

\section{Complications}

As PRP is made of patients own blood, there is no such complications except local site post injection pain seen in 14 patients $(56 \%)$ for some time.

\section{DISCUSSION}

The primary goal of this study was to evaluate the efficacy of intra-articular corticosteroid injection in patients with idiopathic adhesive capsulitis. Various treatment options 
are reported in literature for patients with adhesive capsulitis with variable result. The pathology involved in adhesive capsulitis is synovial hyperplasia and capsular fibroplasia with fibrosis and dense capsular scar formation.

Table 9: Comparisons of constant score during pre and post treatment (PRP).

\begin{tabular}{|c|c|c|c|c|c|c|c|c|c|c|c|}
\hline \multirow[b]{2}{*}{ Pre } & \multicolumn{3}{|c|}{ Post - 1 week } & \multicolumn{4}{|c|}{ Post - 1 month } & \multicolumn{3}{|c|}{ Post - 3 months } & \multirow[b]{2}{*}{ Total } \\
\hline & $\begin{array}{l}\text { o } \\
8 \\
0\end{array}$ & 氜 & $\stackrel{\check{\sigma}}{\check{8}}$ & 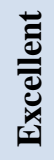 & $\begin{array}{l}\text { Z } \\
8 \\
0\end{array}$ & 灵 & $\stackrel{\overline{8}}{8}$ & 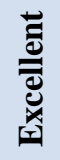 & $\begin{array}{l}\bar{Z} \\
8 \\
0\end{array}$ & $\stackrel{\overline{8}}{2}$ & \\
\hline Fair & 1 & 2 & 0 & 0 & 2 & 1 & 0 & 0 & 3 & 0 & 9 \\
\hline Poor & 4 & 10 & 8 & 1 & 9 & 4 & 8 & 5 & 9 & 8 & 66 \\
\hline Total & 5 & 12 & 8 & 1 & 11 & 5 & 8 & 5 & 12 & 8 & 75 \\
\hline$P$ value & 0.440 & & & 0.5 & & & & 0.15 & & & \\
\hline
\end{tabular}

Test applied: chi-square test.

Table 10: Comparisons of constant score during pre and post treatment (MPS).

\begin{tabular}{|c|c|c|c|c|c|c|c|c|c|c|c|}
\hline \multirow[b]{2}{*}{ Pre } & \multicolumn{3}{|c|}{ Post - 1 week } & \multicolumn{3}{|c|}{ Post - 1 month } & \multicolumn{4}{|c|}{ Post - 3 months } & \multirow[b]{2}{*}{ Total } \\
\hline & 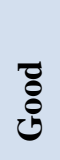 & 氜 & $\stackrel{\check{8}}{\circ}$ & 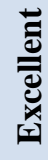 & $\begin{array}{l}\overrightarrow{8} \\
\dot{8} \\
\dot{\theta}\end{array}$ & 春 & $\stackrel{\check{8}}{\circ}$ & 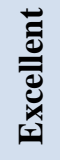 & $\begin{array}{l}\overline{8} \\
8 \\
8\end{array}$ & $\stackrel{\check{0}}{0}$ & \\
\hline Fair & 3 & 0 & 0 & 1 & 2 & 0 & 0 & 1 & 2 & 0 & 9 \\
\hline Poor & 3 & 6 & 13 & 0 & 8 & 2 & 12 & 3 & 7 & 12 & 66 \\
\hline Total & 6 & 6 & 13 & 1 & 10 & 2 & 12 & 4 & 9 & 12 & 75 \\
\hline$P$ value & 0.00 & & & 0.0 & & & & 0.20 & & & \\
\hline
\end{tabular}

Table 11: At 3 months follow.

\begin{tabular}{|lll|}
\hline Results & PRP $(\%)$ & MIPS $(\%)$ \\
\hline Excellent & $5(20)$ & $4(16)$ \\
\hline Good & $12(48)$ & $9(36)$ \\
\hline Poor & $8(32)$ & $12(48)$ \\
\hline
\end{tabular}

Rodeo et al reported role of cytokines and other inflammatory mediators in patients with adhesive capsulitis and Intra-articular corticosteroid decreases synovitis limits development of fibrosis. ${ }^{28,29}$

Hazleman reported success of treatment with intraarticular corticosteroid to be dependent on the duration of symptoms. ${ }^{30}$

Van der Windt et al compared intra-articular corticosteroid to 6 weeks of physical therapy for patients with painful stiff shoulders and reported significant improvements in pain, disability, and motion in the injection group. ${ }^{31}$

Gam et al treated patients with adhesive capsulitis with either steroid injection or steroid injection and distension with $19 \mathrm{~cm} 3$ of Lidocaine. ${ }^{32}$ They found that the distension with steroid group (12 patients) used fewer analgesics and had improved motion compared to the steroid-only group (eight patients).

Bulgen et al in their study treated patients with steroid, physical therapy, ice. ${ }^{33}$ They reported that initial response in steroid group was most significant but no significant difference in final long-term outcome was reported when treatment groups were compared.

Many disadvantages of corticosteroid injection have been reported including periarticular calcification, cutaneous atrophy, cutaneous depigmentation, tendon rupture, avascular necrosis, and joint infection but in our study no significant adverse effect was reported. ${ }^{34}$

In conclusion, corticosteroid injection in the early stages of adhesive capsulitis leads to significant improvement in range of motion and pain.

Our study demonstrated that PRP is not inferior to CS in any of the measured parameters. Both of the groups experienced similar benefits from the injection therapies with no statistical differences detected in ROM or VAS 
scores at 1 week, 1 month and 3 months. No adverse effects were detected in either of the two groups.

Our results are consistent with current literature, showing that PRP can be beneficial treatment of adhesive capsulitis. ${ }^{35,36}$ Previous studies are controversial in interpreting the efficacy of PRP injections due to the different research and treatment protocols, in many cases involving arthroscopy or different products of PRP, for example PRP fibrin matrix. ${ }^{37,38}$

Retrospective design and lack of randomization are the major limitations of this study.

Management of symptoms and improving function are the main goals of the treatment. ${ }^{39,40}$ Current literature strongly advices against surgery in conditions like frozen shoulder and favors conservative treatment options. ${ }^{41}$ In this perspective, PRP may offer a valid alternative to CS, considering that there are no documented significant adverse effects in PRP treatments unlike in CS treatments. ${ }^{35}$ The advantages of PRP over CS are the absence of severe complications locally and systematically. It is safe and simple treatment. Disadvantages of PRP would be more injections required to achieve similar outcomes as a single CS injection. PRP treatment may be repeated whether symptoms return, but multiple CS injections should be avoided. Concurrent physical therapy is still advised because of its proven benefits.

Given the outcomes of our study, we recommend considering PRP as an alternative treatment to CS in order to reduce local and systemic effects involved with $\mathrm{CS}$ injections.

\section{CONCLUSION}

Within the limitations of the study, we can conclude that both PRP and MPS showed efficacy on treating frozen shoulder. The current study provides strong evidence in support of a statistically significant effect of platelet concentrates in the treatment of frozen shoulder in vivo where steroid contraindicated or refused by patient. However, inj. Methylprednisolone has sudden onset of action because of anti-inflammatory action with respect to inj. PRP, so has better result at 1 week follow up post injection. But in long term (at 3 months follow up) inj. PRP has better effect in compared to Inj. MPS.

Funding: No funding sources Conflict of interest: None declared

Ethical approval: The study was approved by the institutional ethics committee

\section{REFERENCES}

1. Chambler AFW, Carr AJ. Aspects of current management. The role of surgery in frozen shoulder. J Bone Joint Surg. 2003;85-B:789-95.
2. Zuckerman J, Cuomo F. Frozen shoulder. In: Hawkins R, ed. The shoulder: a balance of mobility and stability. Rosemont, Il. AAOS. 1993;253-67.

3. MacInnes JD. Perarthritis of Shoulder. Canad MAJ. 1946;55:131-3.

4. Andews JR. Diagnosis and treatment of chronic painful shoulder: Review of nonsurgical interventions. Journal of Arthroscopic and Related Surg. 2005;21(3):333-47.

5. Dhillon RS, Schwarz EM, Maloney MD. Plateletrich plasma therapy - future or trend? Arthritis Res Ther. 2012;14(4):219.

6. Alsousou J, Ali A, Willett K, Harrison P. The role of platelet-rich plasma in tissue regeneration. Platelets. 2012.

7. Bava ED, Barber FA. Platelet-rich plasma products in sports medicine. Phys Sportsmed. 2011;39(3):949.

8. Rockwood CA, editor. The shoulder. Philadelphia: WBSaundersCo. 1990.

9. Codman EA. The shoulder. Boston: Thomas Todd Co. 1934

10. Anton HA. Frozen Shoulder. Can Fam Physician 1993;39:1773-7.

11. Sarwark JF. Essentials of Musculoskeletal Care, ed 4. Rosemont, IL, American Academy of Orthopaedic Surgeons. 2010.

12. Widmer B. Frozen Shoulder. AAOS. 2011.

13. Warner JJP. Frozen Shoulder: Diagnosis and Management. J Am Acad Orthop Surg. 1997;5:130140.

14. Hsu JE, Anakwenze OA. Current review of adhesive capsulitis. J Shoulder Elbow Surg. 2011;20:502-14.

15. Borrione P, Gianfrancesco AD, Pereira MT, Pigozzi F. Platelet-rich plasma in muscle healing. Am J Phys Med Rehabil. 2010;89(10):854-61.

16. Schulte WV. Die Eigenblutfüllung: eine neue Methode zur Versorgung größerer Knochendefkte nach intraoralen Eingriffen. Deutsche Zahnarztliche Zeitschrift. 1960;12:910-4.

17. Schulte WV. Die Retraktion des Blutgerinnsels und ihre Bedeutung Für die primäre Heilung von Kieferknochen. München: Carl Hans Verlag. 1964.

18. Yamamoto K, Hayashi J, Miyamura H, Eguchi S. A comparative study of the effect of autologous platelet-rich plasma and fresh autologous whole blood on haemostasis after cardiac surgery. Cardiovascular Surgery. 1996;4(1):9-14.

19. Whitman DH, Berry RL, Green DM. A technique for improving the handling of particulate cancellous bone and marrow grafts using platelet gel. J Oral Maxillofac Surg. 1998;56:1217-8.

20. Marx RE, Carlson ER, Eichstaedt RM, Schimmele SR, Strauss JE, Georgeff KR. Platelet-rich plasma: Growth factor enhancement for bone grafts. Oral Surgery Endod. 1998;85(6):638-46.

21. Murray MM, Spindler KP, Devin C, Snyder BS, Muller J, Takahashi $\mathrm{M}$ et al. Use of a collagenplatelet rich plasma scaffold to stimulate healing of a 
central defect in the canine ACL. J Orthop Res. 2006;24(4):820-30.

22. Ferrari M, Zia S, Valbonesi M, Henriquet F, Venere $\mathrm{G}$, Spagnolo $\mathrm{S}$ et al. A new technique for hemodilution, preparation of autologous platelet-rich plasma and intraoperative blood salvage in cardiac surgery. Int J Artif Organs 1987, 10:47-50.

23. Storrs C. Is Platelet-Rich Plasma an Effective Healing Therapy? Scientific American. 2009.

24. Sampson S, Gerhardt M, Mandelbaum B. Platelet rich plasma injection grafts for musculoskeletal injuries: a review. Curr Rev Musculoskelet Med. 2008;1:165-74.

25. Marx RE, Garg AK. Dental and Craniofacial Applications of Platelet-Rich Plasma. Carol Stream: Quintessence Publishing Co., Inc. 2005.

26. Academy of Sciences, Paris: M. Donné on the Blood Globules. Prov Med Surg J. 1842;3:498-9.

27. Werner S, Grose R. Regulation of wound healing by growth factors and cytokines. Physiol Rev 2003;83:835-70.

28. Rodeo SA, Hannafin JA, Tom J, Warren RF, Wickiewicz TL. Immunolocalization of cytokines and their receptors in adhesive capsulitis of the shoulder. J Orthop Res. 1997;15:427-36.

29. Bunker TD, Anthony PP. The pathology of frozen shoulder. A Dupuytren-like disease. J Bone Joint Surg Br. 1995;77:677-83.

30. Hazleman BL. The painful stiff shoulder. Rheumatol Phys Med. 1972;11:413-21.

31. van der Windt DAWM, Koes BW, Deville W, Boeke AJP, de Jong BA, Bouter LM. Effectiveness of corticosteroid injections versus physiotherapy for treatment of painful stiff shoulder in primary care. BMJ. 1998;317:1292-6.

32. Gam AN, Schydlowsky P, Rossel I, Remvig L, Jensen EM. Treatment of "frozen shoulder" with distension and glucorticoid compared with glucorticoid alone, a randomized controlled trial. Scand J Rheumatol. 1998;27:425-30.

33. Bulgen DY, Binder AI, Hazleman BL, Dutton J, Roberts S. Frozen shoulder: prospective clinical study with an evaluation of three treatment regimens. Ann Rheum Dis. 1984;43:353-60.

34. Habib GS. Systemic effects of intra-articular corticosteroids. Clin Rheumatol. 2009;28:749-56.

35. Shams A, El-Sayed M, Gamal O, Ewes W. Subacromial injection of autologous platelet-rich plasma versus corticosteroid for the treatment of symptomatic partial rotator cuff tears. Eur J OrthopSurg Traumatol. 2016;26:837-42.

36. von Wehren, L. The effect of subacromial injections of autologous conditioned plasma versuscortisone for the treatment of symptomatic partial rotator cuff tears. Knee Surg Sports TraumatolArthrosc. 2016;24:3787-92.

37. Hurley ET, Lim FD, Moran CJ, Mullett H. The efficacy of platelet-rich plasma and plateletrich brin in arthroscopic rotator cuff repair: A meta-analysis of randomized controlled trials. Am J Sports Med. 2019;47:753-61.

38. Randelli P, Arrigoni P, Ragone V, Aliprandi A, Cabitza, P. Platelet rich plasma in arthroscopicrotator cuff repair: a prospective RCT study, 2-year followup. J Shoulder Elbow Surg. 2011;20:518-28.

39. Lewis J. Rotator cuff related shoulder pain: Assessment, management and uncertainties. Man Ther. 2016;23:57-68.

40. Diercks R. Guideline for diagnosis and treatment of subacromial pain syndrome: a multidisciplinary review by the Dutch Orthopaedic Association. Acta Orthop. 2014;85:314-22.

41. Ketola S, Lehtinen JT, Arnala I. Arthroscopic decompression not recommended in the treatment of rotator cuff tendinopathy: a final review of a randomised controlled trial at a minimum follow-up of ten years. Bone Joint J. 2017;99-B:799-805.

Cite this article as: Juneja J, Jain MP, Choubisa R, Mehra AK, Sen R. Clinical outcome of platelet rich plasma versus steroid in treatment of frozen shoulder. Int J Res Orthop 2021;7:1085-94. 